\title{
Analysis of the possibilities of reducing noise level in mechanical workshop
}

\author{
Analiza możliwości obniżenia poziomu hałasu \\ w warsztacie mechanicznym
}

\begin{abstract}
In the paper problems of noise pollution in the environment of work in small mechanical workshops are presented. In accordance with the standards, noise level measurements were executed in the selected workshop. Taking into account the urban situation of the workshop, a preliminary project has been elaborated to improve the acoustic comfort, which will provide safe working conditions.
\end{abstract}

KEYWORDS: mechanical engineering, noise level, maximum sound pressure, acoustic screens, sound regimes

Taking intensive action to combat noise is very important because it affects a large part of the population. There are about 80 million people in the EU, who are at risk of noise in the working environment, i.e. $1 / 3$ of the working population. In Poland, this number is currently about 190,000 [1]. The aim of this paper is to present a preliminary noise reduction project in a small mechanical plant by applying the basic methods of noise control.

\section{Legal protection against noise in the work environment}

The number of workers exposed to noise is almost three times the number of workers at risk of the second worst-ever industrial pollutant - industrial dust - to which 64,000 people in Poland are exposed (18.9\% of occupational hazards) [2].

\section{Polish regulations on noise in the working environment}

The most important noise regulations in force in Poland include:

- regulation of the Minister of Labor and Social Policy of $6^{\text {th }}$ June 2014 on maximum permissible concentrations and intensities of agents harmful to the health at work [3];

\footnotetext{
* Dr inż. Marianna Kazimierska-Grębosz (marianna.kazimierskagrebosz @p.lodz.pl) - Wydział Organizacji i Zarządzania Politechniki Łódzkiej
}

- norm PN-N-01307:1994 specifying acceptable noise NDN values in the work environment because of the employee's ability to perform basic tasks;

- regulation of the Minister of Economy and Labor of $5^{\text {th }}$ August 2005 on occupational safety and health in work involving noise or mechanical vibration which introduces the so-called threshold values: for exposure levels of eight hour daily working hours or noise exposure levels for the working week, the operating threshold is $80 \mathrm{~dB}$; for peak sound level C, the NDN threshold of $135 \mathrm{~dB}$ is assumed; if the threshold values are exceeded, the employer plans and undertakes actions to reduce occupational risk [4].

\section{Noise testing in selected plant}

- Characteristics of the examined industrial plant. Rapid development, which we observe in almost all areas of life, also concerns machines, devices and technological processes. Newly-established industrial plants operate silent machines and advanced technologies are used, and robots are used in hazardous locations. Working conditions and safety in such establishments are in accordance with the applicable regulations and standards. One should not forget, however, that in the Polish economy, there are industrial plants, small and large, with old machines emitting high noise.

The subject of the study was a small mechanical workshop. Fig. 1 shows the location of machines and noise measurement points in the workshop.

- Noise measurement. Sound level measurements at work stations were carried out in accordance with PNEN ISO 9612:2001. Measurements on individual machines (points $1 \div 10$ in fig. 1 ) were performed during the operation of the machine only. Measurements in the communication and assembly stages were performed during the operation of groups of three machines, because at the same time a maximum of three operators were working in the workshop. Based on the analysis of noise levels emitted by individual machines, four groups were selected: Group I $-T 1+S 1+P$, Group II $-F 1+W$ $+D$, Group III $-T 2+T 3+P$, Group IV $-T 3+F 2+P$. The results are shown in tables I and II. 


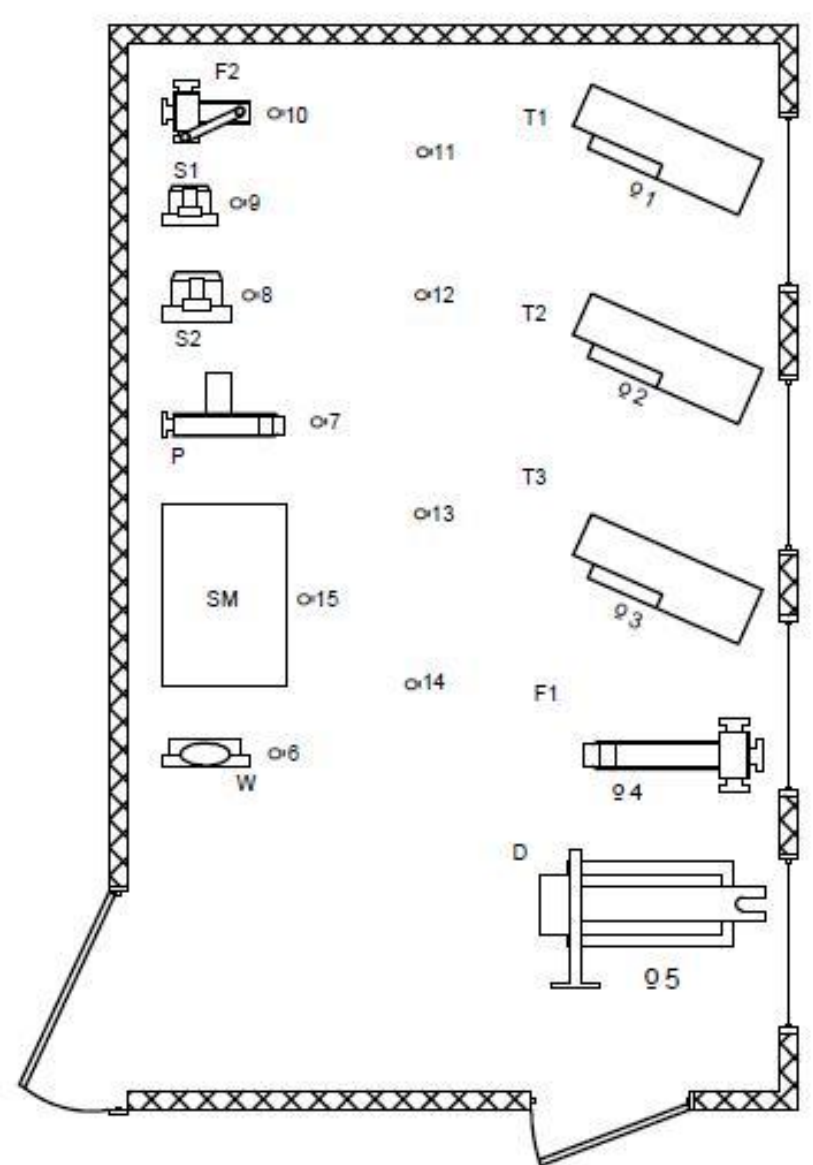

Fig. 1. Location of machines and measuring points in the plant: T1, T2, T3 - universal lathes TUK40; $W$ - column drill; $D$ - glazing machine; F1, F2 - horizontal and vertical milling machines; S1, S2 - table sander SZ 750; $P$ - cutter, $01 \div 15$ - measurement point designation)

TABLE I. Noise level during operation of individual machines

\begin{tabular}{|l|l|l|l|l|l|l|l|l|l|l|}
\hline & \multicolumn{10}{|c|}{ Measurement point number } \\
\cline { 2 - 11 } & 1 & 2 & 3 & 4 & 5 & 6 & 7 & 8 & 9 & 10 \\
\hline $\begin{array}{l}\text { Equivalent } \\
\text { sound } \\
\text { level, dB }\end{array}$ & 75 & 76 & 76 & 73 & 66 & 79 & 91 & 62 & 63 & 75 \\
\hline $\begin{array}{l}\text { Maximum } \\
\text { sound } \\
\text { level, dB }\end{array}$ & 80 & 82 & 83 & 78 & 69 & 85 & 97 & 66 & 75 & 80 \\
\hline
\end{tabular}

\begin{tabular}{|c|c|c|c|c|c|c|c|c|}
\hline \multirow{3}{*}{$\begin{array}{l}\text { Measu- } \\
\text { rement } \\
\text { point } \\
\text { number }\end{array}$} & \multicolumn{8}{|c|}{ Working machines } \\
\hline & \multicolumn{2}{|c|}{$T 1+S 1+P$} & \multicolumn{2}{|c|}{$F 1+W+D$} & \multicolumn{2}{|c|}{$T 2+T 3+P$} & \multicolumn{2}{|c|}{$T 3+F 2+P$} \\
\hline & $L_{\text {AeqT }}$ & $L_{\text {Amax }}$ & $L_{\text {AeqT }}$ & $L_{\text {Amax }}$ & $L_{\text {AeqT }}$ & $L_{\text {Amax }}$ & $L_{\text {AeqT }}$ & $L_{\text {Amax }}$ \\
\hline 1 & 88 & 96 & - & - & - & - & - & $\begin{array}{lll}- & & \\
\end{array}$ \\
\hline 2 & - & - & - & - & 96 & 99 & - & - \\
\hline 3 & 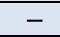 & 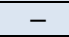 & 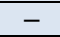 & 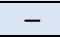 & 88 & 92 & 88 & 90 \\
\hline 4 & - & $\begin{array}{ll}- \\
-\end{array}$ & 81 & 98 & - & - & $\begin{array}{ll}- \\
-\end{array}$ & $\begin{array}{ll}- & \\
-\end{array}$ \\
\hline 5 & - & - & 72 & 90 & - & - & - & - \\
\hline 6 & - & - & 80 & 86 & - & $\begin{array}{lll}- & \\
\end{array}$ & - & - \\
\hline 7 & 92 & 99 & - & - & 95 & 102 & 95 & 99 \\
\hline 9 & 90 & 98 & 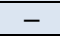 & 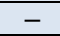 & $\begin{array}{lll}- & & \\
\end{array}$ & - & $\begin{array}{lll}- & & \\
\end{array}$ & $\begin{array}{lll}- & & \\
\end{array}$ \\
\hline 10 & - & - & - & - & - & - & 94 & 98 \\
\hline 11 & 92 & 97 & 74 & 79 & 93 & 98 & 93 & 98 \\
\hline 12 & 94 & 98 & 78 & 84 & 95 & 100 & 94 & 99 \\
\hline 13 & 92 & 98 & 80 & 90 & 91 & 97 & 93 & 98 \\
\hline 14 & 88 & 95 & 80 & 98 & 89 & 94 & 90 & 95 \\
\hline 15 & 91 & 98 & 82 & 89 & 92 & 98 & 91 & 96 \\
\hline
\end{tabular}

\section{Analysis of noise measurement results}

The following conclusions can be drawn from the analysis of the measurement results of equivalent sound level $A$ at the work stations (points $1 \div 10$ ):

- The highest level of noise during operation is emitted by the cutter (point 7). Measurements at this point were made during metal cutting. The $L_{\text {AeqT }}$ level was $91 \mathrm{~dB}$.

- At the work stations of lathes, milling machines, grinders, drills and slotting machines, the noise level did not exceed the permissible value, which was $63 \div 76 \mathrm{~dB}$.

- At no measuring point, no maximum sound level was exceeded, this level was $75 \div 85 \mathrm{~dB}$.

The analysis of results of the noise level measurement in the communication line and on the workstation at the stage (points $11 \div 15$ ) allowed to formulate following conclusions:

- Simultaneous operation of the horizontal milling machine, drill and chisel does not exceed the noise level, $L_{\text {AeqT }}=72 \div 82 \mathrm{~dB}$.

- Incorporation of the cutter increases the noise level at all work stations. The level of $L_{\text {AeqT }}$ in each group of machines was: Group I $(T 1+S 1+P) 88 \div 94 \mathrm{~dB}$; Group III $(T 2+T 3+P) 88 \div 95 \mathrm{~dB}$; Group IV $(T 3+F 2+P)$ $88 \div 94 \mathrm{~dB}$.

\section{Suggestions for changes to reduce noise in the workshop}

Reduction of acoustic comfort in the plant is due to, as demonstrated by measurements, the work of one machine - the cutter.

From a direct interview with the staff, it is clear that there is no way to stop working on this machine, nor can you move it to another room. Therefore, noise reduction measures available in the workshop should be applied. For the owners, it is also important that these funds generate low costs.

- Limitation of noise transmission of the cutter. This can be achieved by using suitable washers - vibroisolators. A wide range of vibration isolators are currently available on the market. Among the materials used in vibration isolation machines, which are most commonly used in insulating elastic-damping elements, rubber is a special place.

- Limitation of noise emission. Machine placement. In order to improve the acoustic comfort of the room, it is necessary to arrange the machines properly. Placing two equally loud noise sources near each other causes an increase in the total acoustic pressure in their environment by $3 \mathrm{~dB}$. The placement of machines in the workshop is unfavorable, especially for people working on the stage. The cutter emits a noise of about $91 \mathrm{~dB}$, thus most of all the machines in the workshop. In addition, it is located in the immediate vicinity of the communication line, the stage, grinders and lathes, whereby the noise emitted by it affects more staff.

Cutter should be placed the in the corner of the room, isolating it from other machines (fig. 2).

Workers rarely use three lathes at the same time. One lathe can be opted out thus gaining more space, which will allow for further changes in the placement of machines. 
Vertical milling machine should be moved next to the horizontal one (fig. 2).

A drill that emits a higher noise level than the grinder should stand next to the cutter (fig. 2).

After the change, the assembly table will be in the "silence zone", next to machines emitting low noise level. The proposed reorganization of workstations does not generate costs.

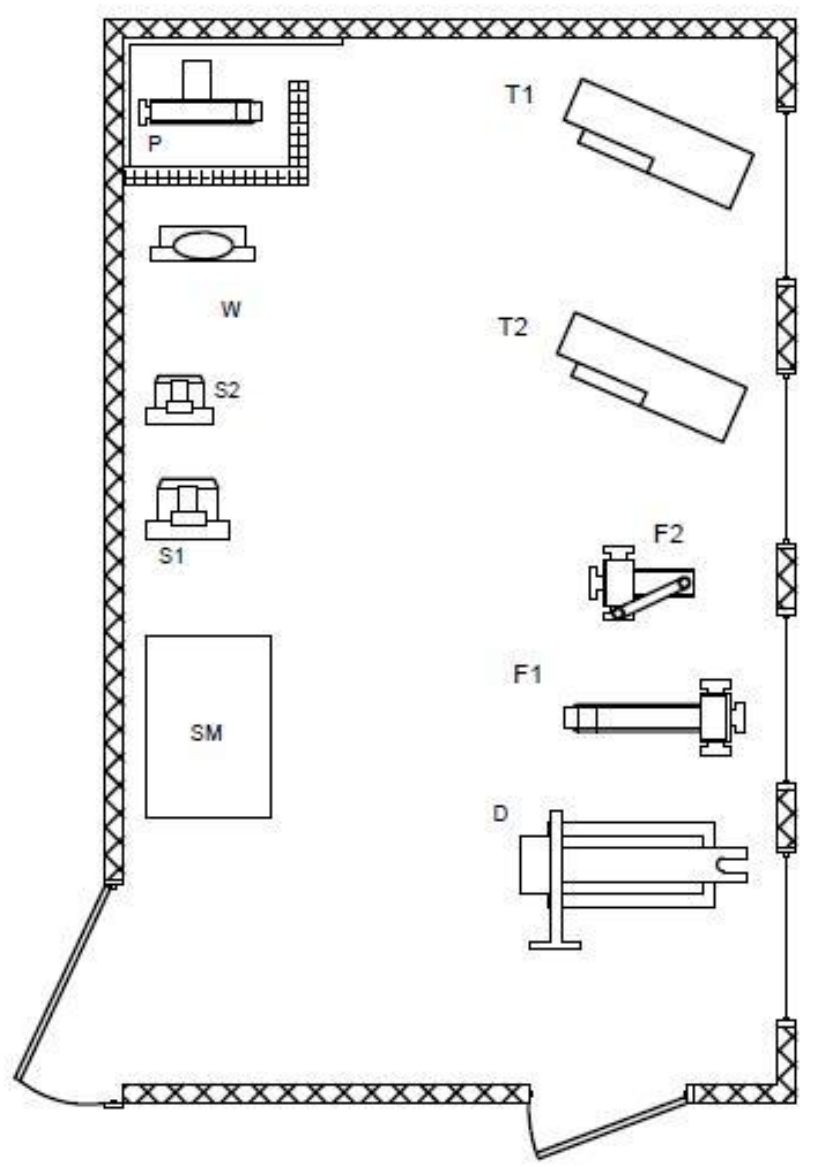

Fig. 2. Placement of machines in the plant after making changes

- Screens and acoustic systems. Noise measurements showed the negative effect of the cutter's work on $L_{\text {AeqT }}$ levels on other workstations. This can be reduced if the angular acoustic screen is positioned at the cutter's stand (fig. 2). The effectiveness of correctly applied sound-insulating screens is estimated at $5 \div 10 \mathrm{~dB}$ at a distance of about $1.5 \mathrm{~m}$ behind the screen, perpendicular to its surface. The use of an angular acoustic screen isolates the cutter from both the communication line and the other machines [5]. The screen is filled with specialist acoustic foam, which is self-extinguishing flame retardant. The screen should consist of two walls of $2 \times 2 \mathrm{~m}$ and $2 \times 1 \mathrm{~m}$ and a thickness of $70 \mathrm{~mm}$.

In order to obtain noticeable noise reduction effects, the walls at the cutter must be covered with soundabsorbing systems, e.g. $10 \mathrm{~mm}$ thick self-adhesive acoustic foam, with non-flammability certificate.

- Personal protective equipment and work organization. In the case of the examined mechanical plant, organizational and administrative funds should be provided to employees in personal protective equipment - insulating inserts and insulators - and the proper organization of work. In this case, better organization of work means the exclusion of simultaneous operation of machines that emit high levels of noise and are adjacent to one another. The implementation of the proposed improvement of acoustic comfort of the plant is not connected at high costs. Costs are often a barrier for small businesses wishing to improve the hygiene and safety of their employees.

Above presented noise reduction measures have already been partially implemented in the workshop. The use of all noise-reducing elements in the plant to be tested should reduce the noise level in the workplace by approximately $10 \mathrm{~dB}$. Then, it will not exceed standards and threaten the health of employees.

\section{Conclusions}

The fight against noise is currently focused on environmental noise, because it affects the largest population. In addition, it is difficult to reduce this kind of noise. One should not forget about the noise in the work environment, which, despite the development of technology, reaches levels that threaten the health of workers. This happens wherever old machines and devices work.

Methods that can be used to prevent this negative effect, are presented on the example of a small mechanical workshop. It is proposed:

- proper placement of machines,

- use of vibration isolators,

- use of acoustic screen,

- change of work organization.

These simple, common methods known to many employees, are not used in many plants, although the implementation of this project does not require a large amount of funding. It is assumed that the use of all the noise-reducing elements in the plant to be tested should reduce the noise level in the workplace by approximately $10 \mathrm{~dB}$.

\section{REFERENCES}

1. Augustyńska D., Pleban D., Radosz J. „Zagrożenie hałasem na stanowiskach pracy w Polsce i innych krajach UE”. Medycyna Pracy. 63, 6 (2012): pp. 689-700.

2. Zgierska A. et all. "Warunki pracy w 2014 roku”. Warszawa: Główny Urząd Statystyczny. 18 (2015).

3. Rozporządzenie Ministra Pracy i Polityki Społecznej z 6 czerwca 2014 r. w sprawie najwyższych dopuszczalnych stężeń i natężeń czynników szkodliwych dla zdrowia w środowisku pracy (Dz.U. 2014.817).

4. Rozporządzenie Ministra Gospodarki i Pracy z 5 sierpnia 2005 r. w sprawie bezpieczeństwa i higieny pracy przy pracach związanych $z$ narażeniem na hałas lub drgania mechaniczne (Dz.U. 2005.157.1318).

5. Kazimierska-Grębosz M., Grądzki R. „Przenośne ekrany akustyczne”. Łódź: Wydawnictwo Politechniki Łódzkiej, 2016. 